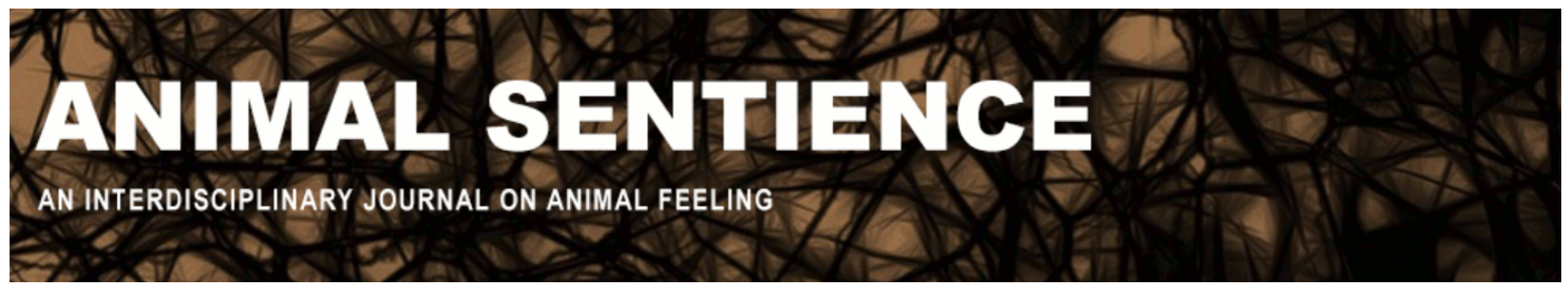

Whitfort, Amanda (2020) China's lack of animal welfare legislation increases the risk of further pandemics. Animal Sentience 30(11)

DOI: $10.51291 / 2377-7478.1639$

Date of submission: 2020-09-02

Date of acceptance: 2020-09-03

(c)

This article has appeared in the journal Animal

Sentience, a peer-reviewed journal on animal

cognition and feeling. It has been made open access,

free for all, by WellBeing International and deposited

in the WBI Studies Repository. For more information,

please contact

wbisr-info@wellbeingintl.org.

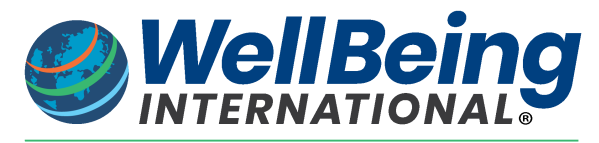

SOLUTIONS FOR PEOPLE, ANIMALS AND ENVIRONMENT 


\title{
China's lack of animal welfare legislation increases the risk of further pandemics
}

\author{
Commentary on Wiebers \& Feigin on Covid Crisis
}

Amanda S. Whitfort

Faculty of Law, University of Hong Kong

\begin{abstract}
Legislation enforcing positive animal welfare standards provides an important buffer against the spread of disease when other safeguards to promote animal health have failed. The continuing absence of animal welfare legislation in China increases the risk of future pandemics, like COVID-19, and puts animal health, and consequently public health in danger.
\end{abstract}

Amanda Whitfort, Associate Professor,
Department of Professional Legal
Education, Faculty of Law, University of
Hong Kong, does research on legislation
promoting animal welfare and
endangered species protection in Hong
Kong and mainland China. Website

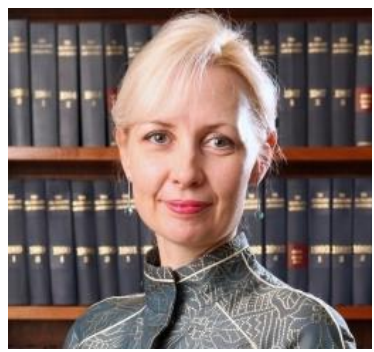

Wiebers \& Feigin (2020) (W\&F) warn that the continued practice of hunting, capturing and trading wild animals for human consumption constitutes a major public health risk. Without significant changes in behaviour we must expect increasingly lethal human zoonosis. The necessity to reduce this risk through increased safeguards for animal health is discussed by Broom (2020) who provides eight international measures to reduce the risk of the next pandemic. These include prohibitions on trade in high-risk species, improved quarantine controls, tightened transport regulations, limitations on numbers of animals in holding facilities and bans on the mixing of species in trade.

Good animal health is inextricably linked with positive animal welfare. Poor welfare can initiate immunosuppression and facilitate the spread of disease amongst animals in trade (Broom 1988).

In the absence of an enforceable international agreement to promote animal health and welfare, it is vital that every nation enact robust laws to ensure the health and welfare of animals in livestock production systems. W\&F link major public health risks to live- animal markets. While China is not alone in utilising such markets for food consumption, the outbreak of COVID-19 has been linked, in the Chinese media, to a food market in Wuhan selling live animals (Cao 2020).

The live wild animals for sale in Chinese markets have several possible origins. Some would have been captive-bred on licensed farms regulated by the Forestry Authority. Others may have been bred illegally on farms, illegal either because the breeding farm had no operating licence or because its licence permitted the breeding of animals other than those it sold. In an attempt to combat sourcing of animals from illegal farms, China has enacted regulations requiring traders to provide certificates of origin for animals sold at markets, however the regulations are poorly enforced and widely flouted (Chow et al. 2014).

Wild animals sold in China's markets may also be sourced from illegal poaching or legal hunting. Legal hunting in China is licensed for non-protected species, subject to quotas (article 
22 China Wildlife Protection Law). Endangered species may be illegally hunted or may have been smuggled into China as part of the lucrative black market trade. It has been reported that live pangolins were offered for sale in the Wuhan market. The sale of pangolin meat in China is prohibited although the use of pangolin scales continues to be permitted for Traditional Chinese medicine (TCM). Commercial breeding of pangolins is not feasible (Challender et al. 2019) and with the Chinese species hunted to extinction in the wild, Viet Nam has become a major source country for illegal pangolins seized in China (Cheng et al. 2017).

Animals on sale in Chinese markets might also be illegally sourced from amongst the key state-protected species farmed under China's Wildlife Protection Law. Article 27 of the Wildlife Protection Law permits these species to be legally bred under licence for so-called 'special purposes' such as to provide the ingredients for TCM (Whitfort 2019). While for the majority of these species their consumption as food is illegal, illegal consumption is known to occur (Zhang et al. 2008).

In the wake of the pandemic, China has prohibited trade in wild animals for human consumption, excluding those species considered low risk. China is currently revising its Wildlife Protection Law and Animal Epidemic Law and enacting a new biosecurity law. However, legislation is only as strong as its enforcement. The security of animal health -- and, consequently, human health -- in China relies on whether the new laws are better enforced than the old ones.

In the absence of adequate safeguards to protect animal health, appropriate animal welfare standards can help to secure the wellbeing of animals and reduce their susceptibility to disease. However, despite years of debate, China has passed no national law to promote animal welfare. The only article which promotes the welfare of wild animals in China is limited to key state-protected species bred under licence for special purposes, such as TCM. Article 26 of the Wildlife Protection Law provides that key state-protected species should have the necessary living space and other conditions required to support reproduction, hygiene and health. Even for these most-protected of wild species, less than a dozen wildlife breeding farms have been credited by the China Forest Certification Council as having satisfactory health and welfare standards for the animals they farm (Wang et al. 2019). Failures to protect welfare have, to some extent, resulted from a lack of resources allocated to enforce adequate standards (Zhao et al. 2012).

Animal welfare laws provide an essential buffer against the spread of zoonotic diseases when other laws, intended to promote animal health, have failed. China's failure to promulgate a national law to safeguard animal welfare presents a continuing danger to animal and public health, locally and globally. ${ }^{1}$

\section{References}

Broom. D.M. (2020) The necessity of human attitude change and methods of avoiding pandemics. Animal Sentience 30(7).

Broom, D.M. (1988) Needs, freedoms and the assessment of welfare Applied Animal Behaviour Science 19:384-386.

\footnotetext{
${ }^{1}$ I expound these arguments further in an article currently under review.
} 
Cao Y. (2020) Taking a Stand. China Daily 2 March 2020.

Challender D. W. S., Sas-Rolfes M., Ades G.W.J., Chin J. S. C, Sun N.C.M, Chong J.L., Connelly E., Hywood L., Luz S., Mohapatra R.K., de Ornellas P., Parker K., Pietersen D.W., Roberton S.I., Semiadi G., Shaw D., Shepherd C.R., Thomson P., Wang Y., Wicker L., Wu S.B., Nash H.C. (2019) Evaluating the feasibility of pangolin farming and its potential conservation impact. Global Ecology and Conservation 20. https://doi.org/10.1016/i.gecco.2019.e00714.

Cheng W., Xing S. and Bonebrake T.C. (2017) Recent Pangolin Seizures in China Reveal Priority Areas for Intervention. Conservation Letters 10(6):757-764. https://doi.org/10.1111/conl.12339

Chow, A. T., Cheung, S., \& Yip, P. K. (2014). Wildlife markets in south china. Human - Wildlife Interactions 8(1):108-112. https://doi.org/10.26077/esnr-ky11

Wang, W., Yang L., Hu Y., Chen S., Huang S., and Xu H. (2019) Performance tracking research of the certification of wildlife feeding management in China. Chinese Journal of Wildlife 40:797-800.

Whitfort A. (2019) China and CITES: Strange Bedfellows or Willing Partners? Journal of International Wildlife Law \& Policy 22(4):342-72. doi 10.1080/13880292.2019.1708558

Wiebers, D.O. \& Feigin, V.L. (2020) What the COVID-19 crisis is telling humanity. Animal Sentience 30(1).

Zhang, L., Hua, N. \& Sun, S. (2008) Wildlife trade, consumption and conservation awareness in southwest China. Biodiversity and Conservation 17:1493-1516. https://doi.org/10.1007/s10531-008-9358-8

Zhao, J., Lan X., Jiang C., and Niu J. (2012) Conservation and utilization of tropical wildlife resources in China. Chinese Journal of Tropical Agriculture 32:106-109. 